\title{
Psychological Response of Students to the Material and Process of Learning in Biology Instructional Methodology Course
}

\author{
Rahmadhani Fitri ${ }^{1 *}$ Lufri Lufri ${ }^{1}$ Relsas Yogica ${ }^{1}$ Arief Muttqiim ${ }^{2}$ \\ ${ }^{1}$ Dept. of Biology, Faculty of Mathematics and Science (FMIPA), Universitas Negeri Padang, Padang, Indonesia \\ ${ }^{2}$ Science Education Department Faculty of Mathematics and Science (FMIPA), Universitas Negeri Padang, Padang, \\ Indonesia
}

"Corresponding author. Email: rahmadhanifitri@fmipa.unp.ac.id

\begin{abstract}
Psychological responses from students to learning in each course are significant. This psychological response can be in the form of students' perceptions, interests, and attitudes towards the material and learning process in a course. This study discusses how psychological responses include perceptions, interests, and attitudes of students towards the Biology Instructional Methodology course to equip teachers candidate to become a professional teacher. Psychological response data were obtained from a questionnaire filled out by students after the Biology Learning Methodology learning process was completed. From the results of the questionnaire, it was found that the common perceptions, interests, and attitudes of students towards the material and learning process of Biology Instructional Methodology courses were good $(83.50 \%)$. It can be concluded that the psychological response of students to the material and learning process of Biology Instructional Methodology courses was in a good category. Keywords: Psychological responses, Biology Instructional Methodology
\end{abstract}

\section{INTRODUCTION}

Learning is a process where there is a relationship between students and their environment, which is planned according to the learning objectives. This is in line with the opinion of Sujana (2005) that "learning is the interaction of students with a learning environment that is designed in such a way as to achieve learning objectives". In this regard, the biology instructional methodology course has one objective so that students can master the basic principles of learning and the scope of the learning methodology (learning strategies). To achieve the learning objectives of this course, one of the factors that play a role in the selection of appropriate learning strategies. As stated by Aqib (2002) that the use of various methods and media can stimulate students to be more active in learning, and in the end, it will also affect learning outcomes for the better. Mulyasa (2005) states that the use of appropriate learning strategies will also determine the value of the effectiveness and efficiency of learning. Appropriate use of learning strategies can be seen in the response and attention of students to the learning strategies used by lecturers. If the learning strategy used by the lecturer can attract student learning interest, it means that the strategy is appropriate to use, conversely if the learning strategy used does not attract students to play an active role in learning means the strategy is not appropriate to use. In addition to learning strategies, learning material is also relevant to note and know how the responses of students.

According to Nurmayatini (2013), in the learning process, interests and attitudes include internal factors within students. Every student must have a different level of interest and attitude. Interest is the primary motivational tool for building desire or enthusiasm for student learning, while attitude is a description of the interests they have. Nurmayatini's research results (2013) note that the relationship of interest and student learning attitudes has a positive direction, meaning that the higher the interest and language attitude of students, the greater the results of the ability of the students' bases.

In the learning process, analyzing students' interests and attitudes towards learning strategies is very important and necessary. High interest in learning strategies allows students to pay great attention to learning strategies and want to participate in learning and will ultimately help students improve better learning outcomes. As stated by Wulandari (2012) that students who have an interest in a particular subject tend to give great attention to the subject and will be more earnest in living it and accompanied by pleasure and attention. With a real interest, it is also assumed that the attitude that will be shown towards the subject will also become more positive.

In addition to interests and attitudes, perception is one of the essential things in the learning process. According to Irwanto (2002), perception is the process of receiving stimuli (objects, qualities, relationships between 
symptoms, and events) until the stimuli are realized and understood. Rakhmad (2005) states that perception is the experience of the object of events or relationships obtained by concluding information and interpreting messages. Furthermore, it can be concluded that the students' perception of the material and learning process is a process that is obtained by students about the experience they have gained after receiving the material and the learning process that has been carried out.

The learning process in the biology instructional methodology course is fundamental, including in the selection of an appropriate learning strategy. The selection of learning strategies in this course is essential because if the learning strategies used are correct. It is assumed that the material delivered and studied will be mastered by students, and students can apply the material in the form of learning strategy simulations. The lecturer has designed a concept approach and drill method in learning, using lecture, discussion, presentation, question and answer methods, and using a modified type of jigsaw cooperative learning model. Also, learning activities are equipped with teaching materials and student worksheets. Lecturers also guide students in discussions and presentations and explain material that is not understood by students.

This article informs about the finding of how the students' psychological responses included perceptions, interests, and attitudes towards the material and learning process of biology learning methodology courses in the Department of Biology FMIPA Universitas Negeri Padang

\section{MATERIALS AND METHODS}

This research was a descriptive study that revealed how students' psychological responses include perceptions, interests, and attitudes towards the material and learning process of biology learning methodology courses. The instrument used was a psychological response questionnaire sheet. Questionnaire data were analyzed using descriptive statistical techniques. Alternative answers to the questionaires statement consisted of strongly agree, agree, disagree, strongly disagree. The distribution of scores obtained from filling out the questionnaire by students was analyzed using the formula modified from Sudjana (2005) below.

$$
P=\frac{\sum s}{S M I} \times 100 \%
$$

\section{Description}

$\begin{array}{ll}\mathrm{P} & \text { : the percentage of scores to be calculated } \\ \mathrm{S} & \text { : total score } \\ \text { SMI } & \text { : maximum number of scores }\end{array}$

The criteria for the analysis of the percentage scores are as follows.

$\begin{array}{ll}85-100 \% & =\text { Very Good } \\ 70-84 \% & =\text { Good } \\ 55-69 \% & =\text { Satisfactory } \\ <55 \% & =\text { Poor }\end{array}$

\section{RESULT AND DISCUSSION}

Psychological responses of students, which include perceptions, interests, and attitudes towards the material and learning process of biology instructional methodology courses were obtained after lectures were held eight meetings. The material given to students includes knowledge about the methodology of biology instruction in the classroom. The details of the learning material delivered have the final goal so that students have the following abilities.

1. Students master the basic principles of learning and the scope of learning strategies.

2. Students understand the role of the teacher and comprehends to control the students in learning activities.

3. Students master the learning material characteristics and the experience to learn biology.

4. Students master various approaches and methods of biology instruction.

5. Students can distinguish the characteristics and syntax of learning models that can be applied in biology instruction.

6. Students are able to display the basic skills of teaching.

7. Students are able to apply knowledge about learning strategies through simulation of the learning process.

To deliver this material, appropriate learning strategy is necessary to be designed. Based on the research that has been done, the lecturer has designed the learning process by using the conceptual approach and drill method. In addition to the two methods, the lecturer also uses lecture, discussion, presentation, question, and answer methods, as well as a modified type of jigsaw cooperative learning model.

The implementation of this research was conducted to students of biology education program, Universitas Negeri Padang. Based on the implementation of research in the form of a learning process, it is necessary to investigate how students respond to the material and learning process of this biology learning methodology course. Based on the results of a questionnaire analysis that has been filled out by students, it is found that the average response of students, which includes perceptions, interests, and attitudes towards the material and the learning process, is good $(83.50 \%)$. The complete analysis results can be seen in the following Figures 1. 


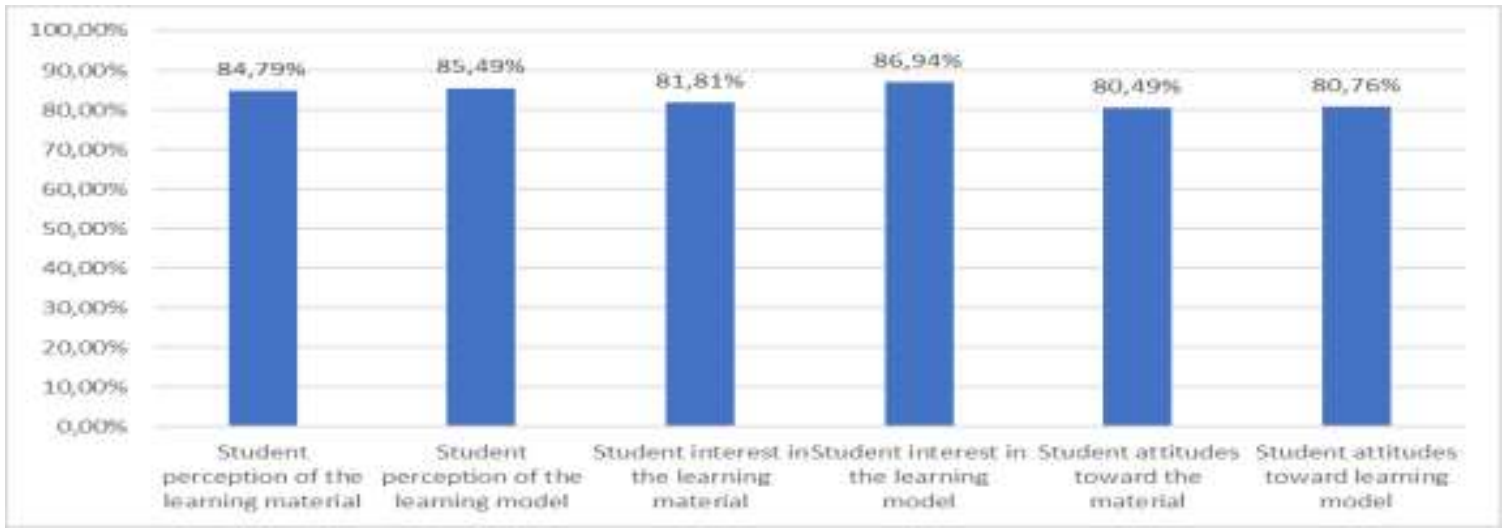

Figure 1. Result of analysis of psychological response of students on materials and learning process of biology instructional methodology course

Based on Figures 1, every aspect of psychological response that includes perceptions, interests, and attitudes towards the material and the learning process has "good" to "very good" criteria. The results showed that students' perceptions of biology instructional methodology material were good. This shows that students view or interpret the learning material as good. According to Sobur (2003), perception is a stimulus or response after a process is carried out. A good perception of this learning material is obtained after the learning materials were given. This means that positive responses or stimuli were obtained after the process of providing and delivering learning material was carried out. This perception of good material was needed in the learning process because if students' perceptions were categorized as good, then the learning process will also be implemented well. This can also have an impact on improving students' competence and discussion of material that is also good. Hilaliyah (2015) revealed that if the perception of learning material is good, the impact is an increase in the learning outcomes of students.

Student perceptions of the biology instructional methodology course materials are influenced by several aspects. Students argue that the course material is understanding, application, analysis, and synthesis. This causes students to get a better understanding of the concepts and processes in the material. In addition, with this form of material students can develop their religious attitude. The course material can also make them do exercises in the form of simulations of applying learning strategies.

The results also showed how students' psychological responses to the material and learning models. Figures 2 to 7 show the percentage of student answers.

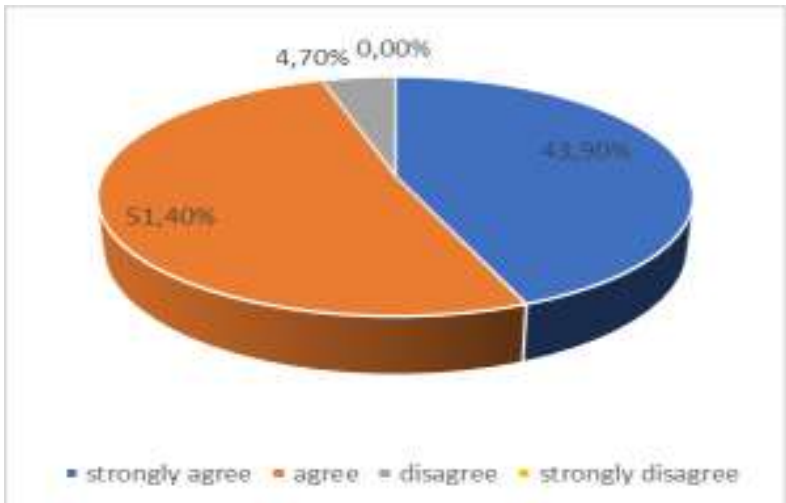

Figure 2. Students have a good perception of the learning material.

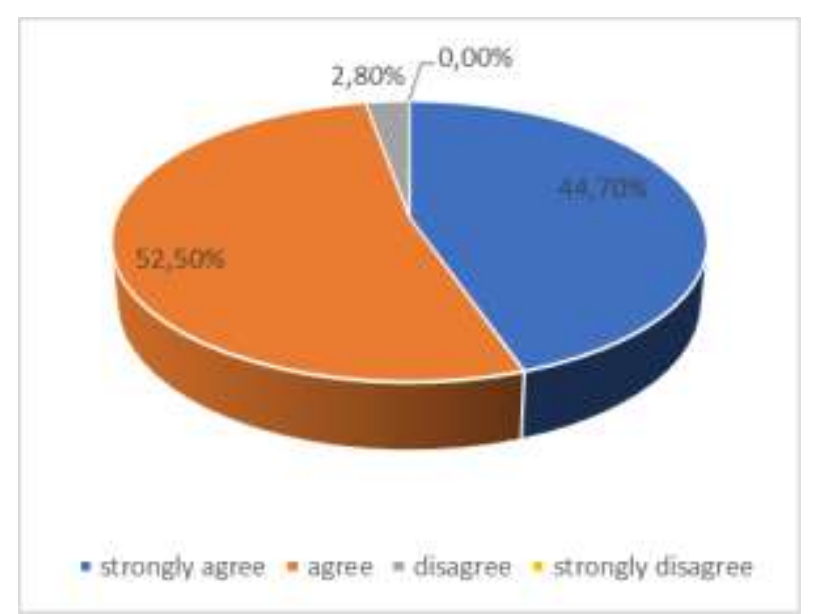

Figure 3. Students have a good perception of the Learning model applied by lecturers 


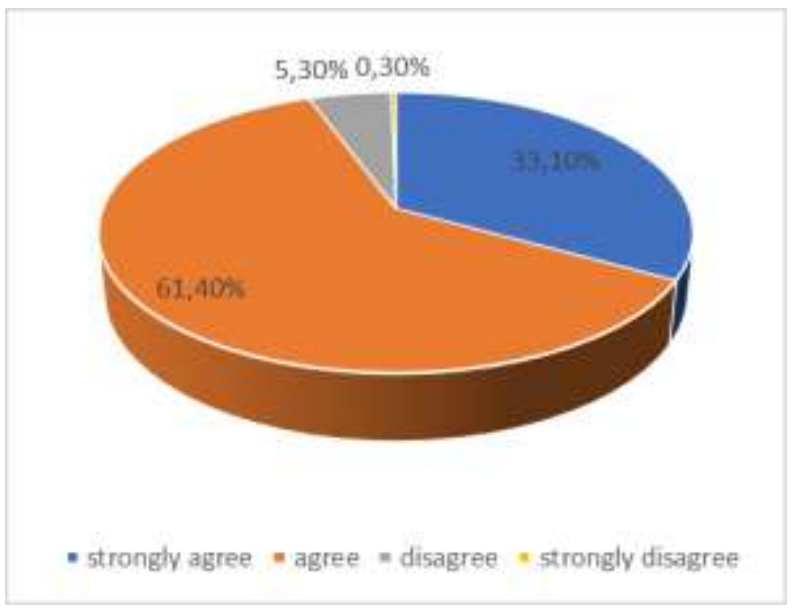

Figure 4. Students interested in learning materials

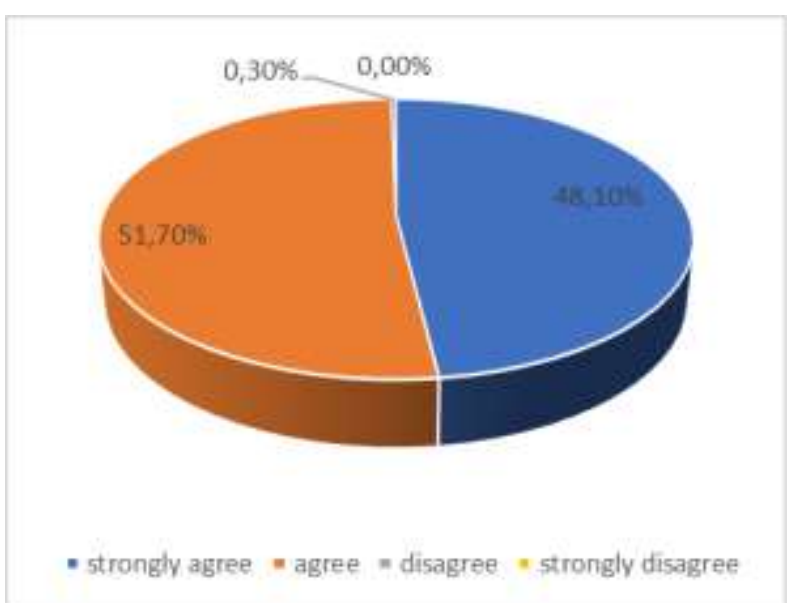

Figure 5. Students interested in the learning model applied by lecturers

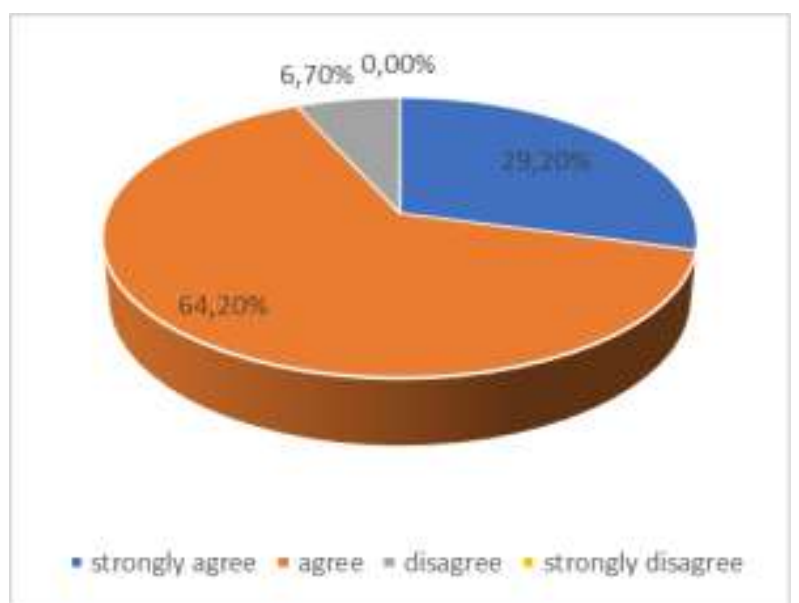

Figure 6. Students behave well toward learning material

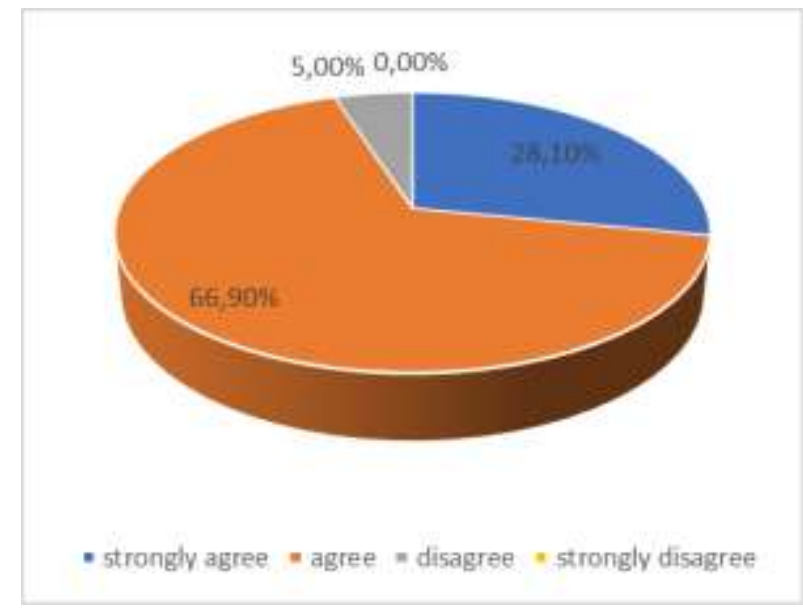

Figure 7. Students behave well towards the learning model applied by lecturers

Adijaya and Santoso (2018) also stated that it is important to know how students' perceptions of learning especially in terms of the use of media or learning materials. It is known that even if the lecturer already thinks that the media or material provided to students is good, the student's perception of the media or material provided by the lecturer is not good. Therefore, there must be a common perception between lecturers and students. Because by knowing how the students' opinions are, the solutions and problems that occur during the learning process can be found and this can be an evaluation material for lecturers.

The results also showed that students' perceptions of the learning model applied by lecturers in the biology learning methodology course were very good. It is also known from the results of the questionnaire analysis that students think that the learning model applied by the lecturer is in accordance with the characteristics of the material, the ability of students, and the time available to carry out the learning process. Students also argue that the learning model applied by lecturers can increase their interest and motivation in learning biology learning methodologies.

The perception of the learning model applied by the lecturer in the excellent learning process is also due to several other things. Among them are students arguing that the model applied by lecturers can stimulate them to think higher level. Besides this learning model can improve some of their abilities, namely the ability to communicate and collaborate. Another thing that causes students to have a very good perception of this learning model is because the model can increase their creativity and critical thinking.

Student perceptions of the learning process, especially regarding the learning model applied by lecturers is very important. As stated by Setyaningsih et al. (2018), knowing students' perceptions of the learning methods/strategies used by lecturers is essential. Pramitasari et al. (2011) previously stated the same thing that if students' perceptions of the model or the method applied by the teacher or lecturer would also affect their learning motivation which would also be better. 
Good student perception of the biology instructional methodology lecture material was also followed by a good interest in the material. This is known from the opinion of students that they are interested and interested in learning material. This is because they like to do the exercises assigned by lecturers and are interested in finding references related to the material and attending seminar student thesis proposals related to biology learning. Therefore, students' interest in learning material is very important to know. Kawet (2017) said that it is necessary to know how students are interested in the material and learning process. Good interest in the material means students think that the material is suitable for the target and interested in learning. If the interest in learning is good then the positive that can be obtained is that learning outcomes will also be good.

Arianingsih and Setiana (2018) stated that high learning interest in students is shown by the students' interest, pleasure, and enthusiasm in attending lectures. This also happened in lectures on biology learning methodology. Students who attend lectures are happy and interested in the material provided by the lecturer.

Student interest in the learning model applied by lecturers in biology instructional methodology courses is very good. This is also known from the opinion of students that the learning model applied by the lecturer makes him interested because the model can motivate them to learn more deeply and make them able to interact in many directions (lecturers, students, lecturers, and students). This also causes them to be able to train and improve their ability to communicate and collaborate. In addition, they have a very good interest in the learning model because the model can increase creativity and high-level thinking. Djaali (2007) stated that interest is a feeling of preference and interest in a thing or activity without anyone asking. Slameto (2010) also said that interest is something to feel more like and feel an interest in a thing or activity without anyone influencing. Interest is the acceptance of a relationship between oneself and something outside of itself. The stronger or closer the relationship, the higher the interest. Interest also has a crucial role in student life and has a significant impact on attitudes and behavior.

Rijal and Bachtiar (2015) stated that interests and attitudes are not the only factors that can influence the high or low student learning outcomes but there are other factors

\section{CONCLUSION}

Based on the research that has been done, it can be concluded that the perceptions, interests, and attitudes of students towards the material and learning process (learning models) in biology learning methodology courses have an average of $83.50 \%$ with good criteria. For students' perceptions and interests in the learning process (learning models) in the biology learning methodology course, the criteria are very good. beyond those interests and attitudes. This is also supported by Walgito (2004) and Susilowati (2015) that if students' interests toward something positive then the attitudes generated will also be positive and together their interests and attitudes will show a positive relationship to learning outcomes.

According to Fitri and Lufri (2017), interest and attitude are some of the factors that can influence each other. If the student's interest in the material and learning model is good then his attitude towards it will also be good. This can be seen from the results of research that has been done that students' attitudes towards the learning materials and models applied by lecturers in the biology instructional methodology lecture are good. As stated by Simanjuntak (2016) that the need to choose a learning strategy that can increase students' interest and ability to discuss and express opinions means that the learning strategy can train communication and collaboration of students.

Abu (2014) states that the attitude of students towards the material and learning process is very important. If students have a negative attitude and are indifferent to it, it will indirectly explain the achievement of students. This will also apply vice versa. If they have a positive attitude then the achievements will also be positive and good. Abu (2014) also added that not only attitudes can influence student achievement; interest will also influence it.

The research conducted produced information that perceptions, interests, and attitudes towards learning materials and models applied by lecturers in biology learning methodology lectures are good. This good response can be predicted that the achievement of student learning outcomes is also good. From the results of evaluations conducted by lecturers on students it is known that the final semester scores of students have an average of 79.86 with good criteria. However, further research is needed regarding the correlation between perceptions, interests, and attitudes of students towards these learning materials and models with the achievements of their learning outcomes in biology learning methodology courses. This is needed so that the information obtained is more valid

\section{ACKNOWLEDGMENT}

Authors thank Direktorat Riset dan Pengabdian Kepada Masyarakat Direktorat Jenderal Riset dan Pengembangan, Kementerian Riset, Teknologi dan Pendidikan Tinggi Republik Indonesia for the funding of this study and Universitas Negeri Padang for all of the support regarding this research process. 


\section{REFERENCES}

Aqib, Z., Profesionalisme Guru Dalam Pembelajaran, Surabaya: Insan Cendekia, 2002.

Mulyasa, E., Menjadi Guru Profesional, Bandung: Remaja Rosdakarya, 2005.

Nurmayatini, E., "Hubungan antara Minat dan Sikap Siswa terhadap Kemampuan Undak-Usuk Basa Sunda Siswa Kelas X9 SMAN 9 Bandung”, Lokabasa, Vol. 4, No.1, pp. 33-40, 2013.

Wulandari, R., "Hubungan antara Minat Belajar dan Sikap Siswa terhadap Mata Pelajaran Akuntansi dengan Prestasi Belajar Akuntansi Siswa Kelas X Program Keahlian Akuntansi SMK YPKK I Sleman Tahun Ajaran 2011/2012”. Skripsi, Yogyakarta: UNY, 2005.

Irwanto, Psikologi Umum: Buku Panduan Mahasiswa, Jakarta: Prenhallindo, 2002.

Rakhmad, J., Psikologi Komunikasi Edisi Revisi, Bandung: Remaja Rosdakarya, 2005.

Adijaya, N. dan L. P. Santosa, "Persepsi Mahasiswa dalam Pembelajaran Online", Wanastra, Vol. 10, No.2, pp. 105-110, September 2018.

Hilaliyah, H., "Pengaruh Persepsi Mahasiswa Atas Bahasa Indonesia dan Minat Belajar terhadap Prestasi Belajar Bahasa Indonesia", Faktor Jurnal Ilmiah Kependidikan, Vol. II, No. 2, pp. 115-122, Juli 2015.

Setyaningsih, N. H., M. Febriani, dan Zuliyanti, "Persepsi Dosen dan Mahasiswa terhadap Pembelajaran Apresiasi Sastra Berperspektif Gender, Jurnal Pendidikan Bahasa Indonesia,Vol. 6, No. 2, pp. 138151, Desember 2018.

Pramitasari, A., Y. Indriana, dan J. Ariati, "Hubungan antara Persepsi terhadap Metode Pembelajaran Kontekstual dengan Motivasi Belajar Biologi Siswa Kelas XI IPA SMAN 1 Pangkalan Kerinci, Riau, Jurnal Psikologi UNDIP, Vol. 9, No. 1, pp. 92-102, April 2011.

Kawet, R. S. I., "Pengarung Metode Pembelajaran dan Minat Belajar Mahasiswa terhadap Belajar Manajemen Konstruksi”, Jurnal Teknologi Pendidikan, Vol. 19, No.3, pp. 224-239, Desember 2017.

Arianingsih, A. dan S. M. Setiana, "Minat Belajar Mahasiswa terhadap Pembelajaran Chookai", Journal of Japanese Language Education and Linguistics, Vol. 2, No. 2, pp. 249-257, Agustus 2018.

Djaali, Psikologi Pendidikan, Jakarta: Bumi Aksara, 2007.
Slameto, Belajar dan Faktor-aktor yang Mempengaruhinya, Jakarta: Rineka Cipta, 2010.

Rijal, S., dan S. Bachtiar, “ Hubungan antara Sikap, Kemandirian Belajar, dan Gaya Belajar dengan Hasil Belajar Kognitif Siswa”, Jurnal Bioedukatika, Vol. 3, No. 2, pp. 15-20, 2015.

Walgito, B., Pengantar Psikologi Umum, Yogyakarta: Andi Offset, 2004

Susilowati, S. Th. "Hubungan antara Kreativitas dan Sikap Belajar dengan Prestasi Belajar Mahasiswa di Jurusan Ortotik Prostetik Politeknik Kesehatan Surakarta", Jurnal Kesehatan, Vol. VI, No. 1, pp. 28-35, 2015.

Fitri, R., dan Lufri, "Hubungan Minat dan Sikap Mahasiswa terhadap Strategi Pembelajaran dengan Capaian Pembelajaran pada Mata Kuliah Metode Penelitian Pendidikan di Jurusan Biologi FMIPA UNP”, Prosiding Semirata 2017 Bidang MIPA BKSPTN Wilayah Barat, Jambi, 12-14 Oktober 2017, pp. 3264-3272.

Simanjuntak, E., "Sikap Mahasiswa terhadap Pembelajaran Aljabar Linier Elementer dengan Reciprocal Teacching", Inspiratif,Vol. 2, No. 2, pp. 20-30, April 2016.

Abu, N. E. B., "Hubungan antara Sikap, Minat, Pengajaran Guru dan Pengaruh Rakan Sebaya terhadap Pencapaian Matematik Tambahan Tingkatan 4", Jurnal Kurikulum dan Pengajaran Asia Pasifik, Bil. 2, Isu. 1, pp. 1-10, Januari 2014. 